\title{
MINERAL RESOURCE POTENTIAL OF THE COYOTE SE AND TABLE MOUNTAIN ROADLESS AREAS, INYO COUNTY, CALIFORNIA
}

\author{
SUMMARY REPORT
}

By

Geoffrey S. Elliott and Maurice A. Chaffee

U.S. Geological Survey

and

Donald O. Capstick

U.S. Bureau of Mines

\section{STUDIFS RELATED TO WILDERNESS}

Under the provisions of the Wilderness Act (Public Law 88-577, September 3, 1964) and related acts, the U.S. Geological Survey and the U.S. Bureau of Mines have been conducting mineral surveys of wilderness and primitive areas. Areas officially designated as "wilderness," "wild," or "canoe" when the act was passed were incorporated into the National Wilderness Preservation System, and some of them are presently being studied. The act provided that areas under consideration for wilderness designation should be studied for suitability for incorporation into the Wilderness System. The mineral surveys constitute one aspect of the suitability studies. The act directs that the results of such surveys are to be made available to the public and be submitted to the President and the Congress. This report discusses the results of a mineral survey of the Coyote SE (5033) and Table Mountain (5035) Roadless Areas in Inyo National Forest, Inyo County, California. The areas were classified as further planning areas during the Second Roadless Area Review and Evaluation (RARE II) by the U.S. Forest Service, January 1979 .

\section{SUMMARY}

A combined geologic and geochemical investigation and a survey of mines, prospects, and alterec areas indicate that the Coyote SE and Table Mountain Roadless Areas contain some areas that have a low resource potential for tungsten and marble. Metallic mineral occurrences in these roadless areas are in metasomatic replacement-type tactite deposits. Tungsten, in the mineral scheelite, is the most important metal found in this region; other metals including molybdenum, copper, gold, and silver occur in small amounts in the tactite. A low resource potential for uranium exists in a small area of the southwestern part of the Coyote SE Roadless Area. Scheelite-bearing tactite with a low resource potential is identified at the Middle Fork Shannon prospects in the Coyote SE area and at the Chipmunk (Pickup) and Marble Tungsten mines adjacent to or along the area boundary; the Marble Tungsten mine also has a low resource potential for marble. A low resource potential for marble was also identified at quarries in the southeast corner of the Coyote SE Roadless Area. The Waterfall prospect on the boundary of the Table Mountain Roadless Area has a low resource potential for tungsten.

\section{INTRODUCTION}

The Coyote SE and Table Mountain koadless Areas lie along the eastern front of the Sierra Nevada between Bishop and Big Pine, Inyo County, Calif. (fig. 1). They include approximately 58,300 acres in Inyo National Eorest.

The two areas are east of the main crest of the Sierra Nevada, and range from about $12,000 \mathrm{ft}$ above sea level near the center of the Coyote SE Roadless Area to about 4,000 ft in the Owens Valley near Bishop. The climate is semiarid and the vegetation sparse because the area is in the rainshadow of the Sierra Nevada crest. Primary access to the Coyote SE area from the north is by a steep four-wheel-drive dirt road. Several other dirt roads reach the roadless-area boundaries, including the Shannon Road in Shannon Canyon. Access from the south is along Big Pine Creek on Big Pine Creek Road. California Highway 168 to Lake Sabrina and South Lake provides access to the lower elevations of the Table Mountain Roadless Area; the South Lake road also provides access to the lower elevations of the Coyote SE area.

\section{Previous and present studies}

The region, including the two roadless areas, was mapped in detail by Bateman (1965). The U.S. Geological Survey (Elliott and MeKee, 1982) compiled a new geologic map using the mapping by Bateman and information in Moore and Foster (1980) and Stern and others (1981). A simplified version of this map is used in the accompanying map sheet. A tabulation of chemical analyses made as part of a geochemical study was published by Elliott and others (1982). The U.S. Bureau of Mines searched literature and county mining records for information on mines, prospects, and mineralized areas prior to conducting field investigations. Three hundred and twenty-two samples were collected from mines, prospects, and mineralized areas for analysis. Prominent mines and prospects in and near the roadless areas are described in table 1 and some are shown in figure 2 .

\section{GEOLOGY AND GEOCHEMISTRY PERTAINING TO MINERAL RESOURCE ASSESSMENT}

\section{GEOLOGIC SETTING}

The area covered by this report records a complex geologic history involving Paleozoic iniogeosynclinal sedimentation, late Paleozoic and Mesozoic deformation, Vesozoic plutonism, and Cenozoic igneous activity and basinand-range faulting. The rocks can be divided into the following four major groups: (1) lower Paleozoic through middle Paleozoic metasedimentary rocks consisting of marble, pelitic hornfels, micaceous quartzite, schist, and metachert; (2) upper Paleozoic metavolcanic rocks, mostly meta-andesite with some felsic types; (3) granitic rocks, mostly granodiorite, that were intruded in Late Triassic to 
Iate Cretaceous time; (4) basaltic and andesitic intrusive and extrusive rocks of Miocene age. The Miocene volcanic rocks were erupted onto ancestral basin-and-range topography along faults that later controlled the structural development of Owens Valley and the eastern Sierra front.

\section{Paleozoic rocks}

Paleozoic rocks of the Coyote SE and Table Mountain Roadless Areas are metamorphosed strata of shallow-marine shelf facies that were deposited during late Precambrian to Devonian time as part of a clastic wedge at the west edge of the North American craton. Late Paleozoic compressional deformation resulted in tight folding and faulting with north to northwest trends. Intrusion of the Sierra Nevada batholith in Mesozoic time metamorphosed shale and siltstone to pelitic hornfels; marl and siliceous dolomite to calc-hornfels; limestone to marble and locally to tactite; sandstone to quartzite; and chert to metachert.

The largest cluster of metasedimentary rocks in the study area is called the Bishop Creek pendant (see accompaning map) which covers approximately $20 \mathrm{mi}^{2}$ and includes some $6,500 \mathrm{ft}$ of strata. These rocks range in age from Early Ordovician to Devonian (Moore and Foster, 1980). A much smaller cluster to the south is called the Big Pine Creek pendant (Moore and Foster, 1980). Other uncorrelated metamorphic septa are scattered throughout the study area. Upper Paleozoic volcanic rocks, mostly metaandesite and some silicic rock types, crop out in the study area.

\section{Mesozoic rocks}

Triassic to Late Cretaceous granitic rocks of the Sierra Nevada batholith underlie most of the Coyote SE and Table Mountain Roadless Areas. The granitic rocks include hornblende gabbro, quartz diorite, granodiorite, quartz monzonite, granite, and alaskite (Bateman, 1965; Elliott and McKee, 1982).

The oldest intrusive bodies are mafic, consisting of hornblende gabbro and quartz diorite. These small bodies occur as inclusions, pendants, and septa between the silicic granitic plutons throughout the area. Intruding these mafic rocks is the Tungsten Hills Quartz Monzonite, dated by U-Pb at about $200 \mathrm{~m} . \mathrm{y}$. (Stern and others, 1981). Underlying most of the southeastern part of the study area are Jurassic granitic rocks which are light-gray medium-grained biotitehornblende quartz monzonite dated at 167 m.y. by the U-Pb method (Stern and others, 1981). About three-fourths of the eastern Sierra Nevada range front between Bishop and Big Pine is underlain by the leucogranite of Rawson Creek. The leucogranite of Rawson Creek has been dated at $95 \mathrm{~m} . \mathrm{y}$. by Stern and others (1981). The granodiorite of Coyote Flat underlies much of the central part of the Coyote SE Roadless Area. Kistler and others (1965) obtained a K-Ar age on a biotite of 90 m.v. from this unit. Dikes of aplite and pegmatite are also present. These dikes are similar in composition and probably related to the leucogranite of Rawson Creek.

\section{Cenozoic rocks and surficial deposits}

Basaltic dikes and dissected lava flows of late Cenozoic age crop out over a small part of the northeast end of the Coyote SE Roadless Area. The dissected flows are remnants of a once more extensive basaltic cap and the north-trending dikes in the central part of this roadless area are the remains of feeders. The volcanic rocks were erupted onto ancestral basin-and-range topography along faults that later controlled the structural development of Owens Valley and the eastern Sierra front. One flow in the northern part of the Coyote SE Roadless Area was dated at 9.6 m.y. by the KAr method (Dalrymple, 1963).

Several types of Quaternary surficial deposits are present in the roadless areas including glacial till of several ages and modern stream and alluvial fan deposits. These surficial deposits record a history of climatic variation as well as considerable vertical offset along basin-and-range faults during the past few million years.
The U.S. Geological Survey collected 64 rock, 90 stream-sediment, and 90 nonmagnetic heavy-mineralconcentrate samples from drainage basins in the Coyote SE and Table Mountain Roadless Areas. They were processed for geochemical analysis for use in this report. Analyses of the rock sainples from unaltered outcrops indicate the chemical abundances in typical rock material; analyses of the streamsediment and nonmagnetic heavy-mineral-concentrate samples indicate the overall chemistry of the minerals present in eroded rock material from the entire drainage basin upstream from each sample site. The higher concentrations of selected minerals in the nonmagnetic heavy-mineral samples, relative to their concentration in stream-sediment samples, permits determination of some elements that are not commonly detected in stream-sediment samples.

All samples were analyzed for 31 elements by six-step semiquantitative emission spectroscopy. The rock and stream-sediment samples were also analyzed for zine by atomic-absorption spectrometry, for gold by flameless atomic-absorption spectrometry, and for uranium by fluorometry. A tabulation of these analyses is given in Elliott and others (1982).

The drainage basins from which the eroded material containing anomalous values originated were evaluated by assigning a numerical score dictated by the number of anomalous metals and their actual concentrations in streamsediment and panned-concentrate samples. A map was produced (Donahoe and Chaffee, 1983) showing drainage basins with high seores and an explanation of the results.

All of the drainage basins with high scores contain outcrops of the metamorphosed sedimentary rocks that have been intruded and altered by granitic plutons of the Sierra Nevada batholith. This suggests that contact-metasomatic mineral deposits are the source of the metals detected. The geochemical anomalies in these drainage basins are characterized in general by anomalies of one or more of the elements $\mathrm{Ag}, \mathrm{As}, \mathrm{Au}, \mathrm{B}, \mathrm{Be}, \mathrm{Bi}, \mathrm{Cd}, \mathrm{Co}, \mathrm{Cu}, \mathrm{Fe}, \mathrm{Mn}$, $\mathrm{Mlo}, \mathrm{Pb}$, $\mathrm{Sn}, \mathrm{W}$, and $\mathrm{Zn}$. This suite of elements, taken in conjunction with the geologic environment in these areas, suggests that precious-metal-rich contact-metasomatic tungsten deposits of the tactite type may be present in any or all of these anomalous drainage basins.

U.S. Bureau of Mines rock samples were fire assayed for gold and silver, analyzed for tungsten by inductioncoupled argon-plasma spectrography, and analyzed for base metals by atomic-absorption methods. The results were used to identify metallic mineral occurrences and to aid in resource evaluation.

\section{MINING DISTRICTS AND MINERALIZED AREAS}

The Coyote SE and Table Mountain Roadless Areas are within the Bishop Creek mining district, a subdivision of the Bishop mining district which is noted for its tungsten production. The first prospecting, particularly for gold, was carried out by the earliest settlers to this region in the late 1800 's. The only significant producer of rold within the Bishop distriet was the Cardinal mine, west of Table Mountain Roadless Area (fig. 2). It was operated from 1911 to 1922 and from 1934 to 1940 , and produced $\$ 1.6$ million in gold (Tucker and Sampson, 1938). This mine, as well as several small gold properties worked during the depression years of the 1930 's, was closed at the beginning of World War II and has never reopened.

Tungsten prospecting began in the Bishop district in 1913 when scheelite was found in Deep Canyon in the Tungsten Hills $4 \mathrm{mi}$ north-northeast of the Coyote $\mathrm{SE}$ Roadless Area (fig. 2). Since then, tungsten mining has continued only sporadically due to tremendous fluctuations in the price of tungsten. One thousand tons of tungsten trioxide $\left(\mathrm{WO}_{3}\right)$ had been produced from the area prior to World War II; present production for the Tungsten Hills is small.

Thirty-two mining properties were assessed within and along the boundaries of the roadless areas, the prominent properties being included in figure 2 . All but one were 
tungsten prospects. Two, the Marble Tungsten and the Schober and associated properties, produced 8,000 stu (a short ton unit (stu) contains $20 \mathrm{lb}$ of $\mathrm{WO}_{3}$ ) and 10,000 tons of approximately 0.5 percent $\mathrm{wO}_{3}$, respectively. Several other properties that lie outside but close to the roadless areas were tungsten producers, including the Bakock, Chipmunk, Linder, Marble Tungsten, and the Rossi mine which produced over 10,000 stu $\mathrm{WO}_{3}$. For a more complete listing, see table 1. No active mines are present in the Coyote SE or Table Mountain Roadless Areas today.

Non-metallic minerals have been mined near the roadless areas. Small amounts of antimony ore were shipped from the Bishop Antimony mine (fig. 2) in the early part of World War II. Kaolinite from the Nebecita Feldspar-Kaolin and the Sierra White Feldspar deposits (fig. 2) has been mined on a limited basis. The Blue Star mines (fig. 2) produced talc as recently as 1945 and marble used for roofing material was quarried from this mine, the Marble Tungsten mine, and from unnamed quarries next to the southeast boundary of the Coyote SE area. Though close to the Coyote SE Roadless Area, these deposits do not extend into the roadless area.

\section{Coyote SE Roadless Area}

A search of Inyo County records revealed a total of 236 lode and 10 placer claims in or near the Coyote SE Roadless Area. The earliest claims in the area were located in 1879. There are 15 inactive tungsten mines and prospects in the Coyote SE Roadless Area, and eight adjacent to or on the boundary (table 1). The Middle Fork Shannon prospect has 2,900 tons of low-grade tungsten resources averaging 0.24 percent tungsten trioxide ( $\left.\mathrm{WO}_{3}\right)$. The Chipmunk II (Brown) and two other prospects have a low resource potential for tungsten and (or) silver. Adjacent to the study area, the Chipmunk (Pickup) and Marble Tungsten mines have 18,000 and 4,000 tons of low-grade tungsten-bearing reserves averaging 0.50 and 0.54 percent $\mathrm{WO}_{3}$, respectively. In addition to tungsten, the Marble Tungsten mine has 800,000 tons of low-quality marble resources. The Bakock mine has a low resource potential for tungsten and marble resources, while two quarries on a nearby unnamed property have a low potential for marble; both properties are near the study-area boundary. Two additional prospects on the roadless-area boundary, the Slim Chance and an unnamed property, have a low resource potential for tungsten.

\section{Table Mountain Roadless Area}

A search of Inyo County records revealed a total of 34 lode claims and one placer claim in or near the Table Mountain Roadless Area. No patented claims exist within the roadless area; the earliest claims were located in 1902 . The Waterfall prospect and the Stevens prospect (fig. 2) located outside the roadless area, contain scheelite-bearing tactite in small marble pods. These deposits are small, discontinuous, and of low grade (table 1). The Waterfall prospect has a low resource potential for tungsten.

\section{ASSESSMENT OF MINERAI, RESOURCE POTENTIAL}

Tactite containing tungsten resources is identified in and near the Coyote SE and Table Mountain Roadless Areas. In addition to tungsten, which is the most important metal in this rock type, gold, silver, copper, and molybdenum are present as secondary elements. Because the tactite bodies are small and low grade, the resourse potential for tungsten and others metals within the Coyote SE and Table Mountain Roadless Areas is low.

\section{Coyote SE Roadless Area}

Metamorphic rocks, including some tactite, occur in the Coyote SE Roadless Area. Significant concentrations of metallic minerals in these tactites are rare, however, and most of the surface deposits have probably been found. Stream-sediment and panned-concentrate samples from drainages that cut the Bishop Creek roof pendant and also metamorphic rocks at the north end of the study area and in
Shannon Canyon contain slightly anomalous concentrations of $\mathrm{Ag}, \mathrm{Au}, \mathrm{B}, \mathrm{Bi}, \mathrm{Co}, \mathrm{Cu}, \mathrm{Fe}, \mathrm{Mo}, \mathrm{Pb}, \mathrm{Sn}, \mathrm{W}$, and $\mathrm{Zn}$. The overall low concentration of these elements in these samples suggests that the possibility of metal-rich deposits is small. Weakly to moderately anomalous levels of uranium were found in stream-sediment samples in the southwesternmost part of the Coyote SE Roadless Area. Neither the source area nor the uranium-bearing mineral is known for this element. Based on the concentrations of uranium, the resource potential for uranium is low.

Known and potential mineral resources are within or near the northern, southeastern, and western parts of the Coyote SE Roadless Area and in Shannon Canyon on the east side. Tungsten-bearing tactite occurs in the inactive Chipmunk and Marble Tungsten mines outside the roadless area (fig. 2). The resource potential in these mines is considered low because of low to moderate grade and small tonnage of identified deposits.

\section{Table Mountain Roadless Area}

Analysis of samples of tactite from the Waterfall prospect, near the Table Mountain Roadless Area, suggests a low resource potential for tungsten. This potential is substantiated by anomalous amounts of $\mathrm{Ag}, \mathrm{Au}, \mathrm{B}, \mathrm{Bi}, \mathrm{Cu}, \mathrm{W}$, and $\mathrm{Zn}$ in stream-sediment and panned-concentrate samples in areas including and adjacent to the Waterfall prospect in the Bishop Creek roof pendant. This suite is associated with tactite mineralization (Rose and others, 1979).

\section{REFERENCES}

Bateman, P. C., 1965, Geology and tungsten mineralization of the Bishop district, California: U.S. Geological Survey Professional Paper 470, $208 \mathrm{p}$.

1956, Economic geology of the Bishop tungsten district, California: California Division of Mines Special Report $417,87 \mathrm{p}$.

Capstick, D. O., and Stump, A. L., 1983, Mineral investigation of the Coyote SE RARE II Area (No. 5033), Inyo County, California: U.S. Bureau of Mines Mineral Land Assessment MLA 84-83.

Dalrymple, G. B., 1963, Potassium-argon dates of some Cenozoic volcanic rocks of the Sierra Nevada, California: Geological Society of America Bulletin, v. 74 , no. 4 , p. $379-390$

Donahoe, J. L., and Chaffee, M. A., 1983, Geochemical anomaly map of the Coyote $\mathrm{SE}$ and Table Mountain Roadless Areas, Inyo County, California: U.S. Geological Survey Miscellaneous Field Studies Map MF-1426-C, scale $1: 62,500$.

Elliott, G. S., and McKee, E. H., 1982, Geologic map of the Coyote SE and Table Mountain Roadless Areas, Inyo County, California: U.S. Geological Survey Miscellaneous Field Studies Map MiF-1426-A, scale $1: 62,500$.

Ellintt, G. S., Diggles, M. F., Chaffee, M. A., Fey, D. L., Sutley, S. J., Hill, R. H., and Van Gaalen, Glen, 1982, Chemical analyses of sainples of rock and stream sediment, and nonmagnetic heavy-mineral concentrate, Coyote SE and Table Vountain Roadless Areas, Inyo County, California: U.S. Geological Survey Open-File Report 82-996, 116 p., 1 plate.

Kistler, R. W., Bateman, P. C., and Brannock, W. W., 1965, Isotopic ages of minerals from granitic rocks of the central Sierra Nevada and Inyo Mountains: Geological Society of America Bulletin, v. 76, no. 2, p. 155-164.

Lemmon, D. M., 1941, Tungsten deposits in the Sierra Nevada rear Bishop, California: U.S. Geological Survey Bulletin 931-E, p. 79-104.

Moore, J. N., and Foster, C. T., Jr., 1980, Lower Paleozoic metasedimentary rocks in the east-central Sierra Nevada, California: Correlation with Great Basin formations: Geological Society of America Bulletin, v. 91, p. 37-43.

Rose, A. W., Hawkes, H. E., and Web, J. S., 1979, Geochemistry in Mineral exploration: London, Academic Press, 657 p. 
Stern, T. W., Bateman, P. C., Morgan, B. A., Newell, M. F., and Peck, D. L., 1981, Isotopic U-Pb ages of zircon from the granitoids of the central Sierra Nevada, California: U.S. Geological Survey Professional Paper $1185,17 \mathrm{p}$
Tucker, W. B., and Sampson, R. J., 1938, Mineral resources of Inyo County: California Journal of Mines and Geology, v. 34, p. $368-500$.

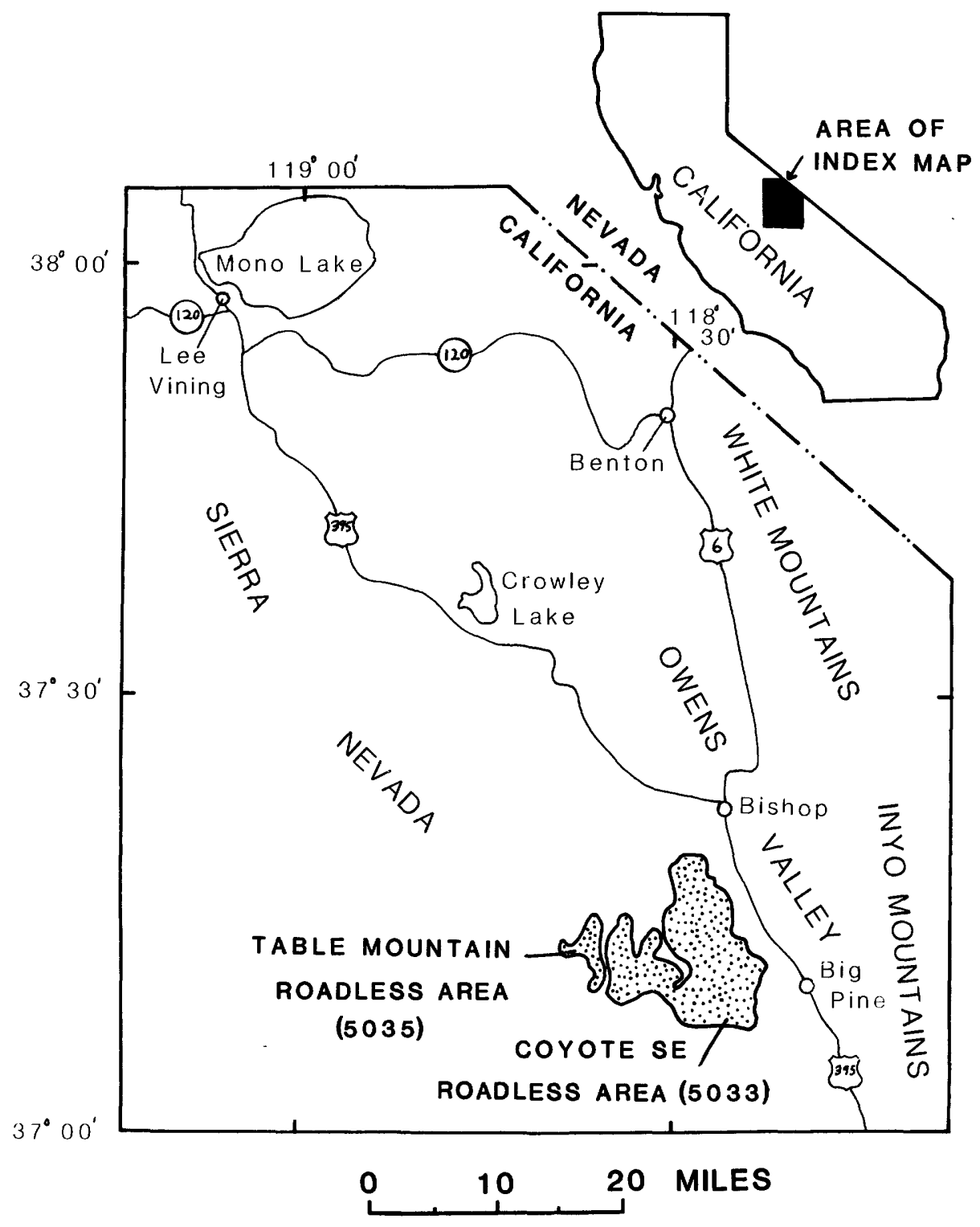

Figure 1--Index map showing location of roadless areas. 


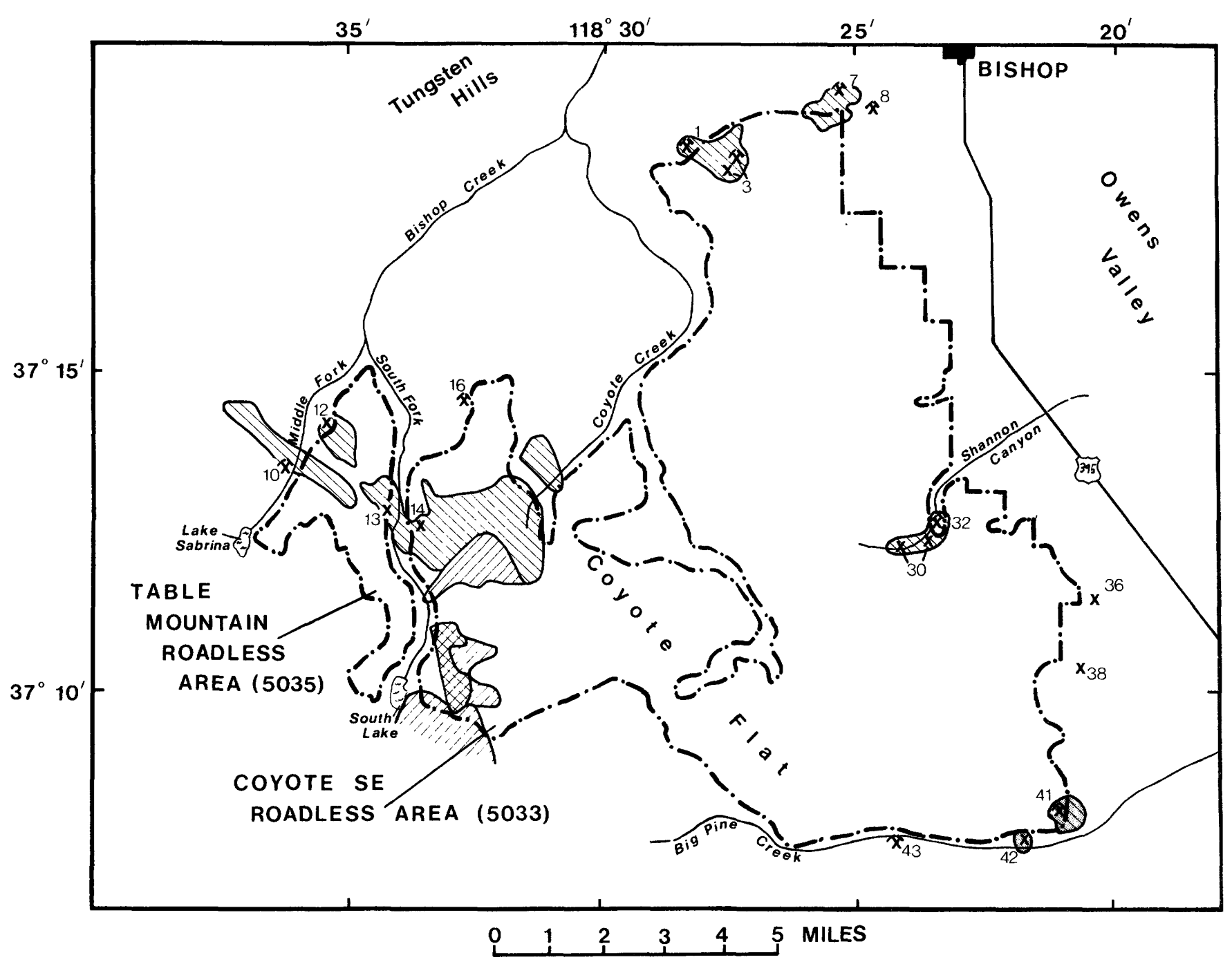

EXPLANATION

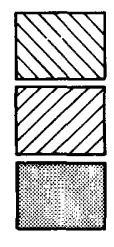

AREA OF LOW RESOURCE POTENTIAL FOR TUNGSTEN

AREA OF LOW RESOURCE POTENTIAL FOR URANIUM

AREA OF LOW RESOURCE POTENTIAL FOR MARBLE

$$
\begin{aligned}
& x^{7} \text { MINE--Number refers to list } \\
& \text { of mines and prospects } \\
& x^{3} \text { PROSPECT--Number refers to } \\
& \text { 1ist of mines and prospects } \\
& \text { APPROXIMATE BOUNDARY OF } \\
& \text { ROADLESS AREAS }
\end{aligned}
$$

\begin{tabular}{|c|c|c|c|c|c|}
\hline 41 & Bakock mine & 32 & Marble Tungsten mine & 16 & Schober mine \\
\hline 7 & Bishop Antimony mine & 30 & Middle Fork Shannon & 38 & Sierra White Feldspar \\
\hline 43 & Blue Star mines & & prospects & & deposit \\
\hline 10 & Cardinal mine & 36 & Nebecita Feldspar- & 14 & Slim Chance prospect \\
\hline 1 & Chipmunk (Pickup) mine & & Kaolin deposit & 12 & Stevens prospect \\
\hline 3 & $\begin{array}{l}\text { Chipmunk II (Brown) } \\
\text { mine and prospect }\end{array}$ & $\begin{array}{r}42 \\
8\end{array}$ & $\begin{array}{l}\text { Marble quarries } \\
\text { Rossi Tungsten mine }\end{array}$ & 13 & Waterfall prospect \\
\hline
\end{tabular}

LIST OF MINES AND PROSPECTS

(in alphabetical order)

Figure 2.--Mineral resource potential of the Coyote SE and Table Mountain Roadless Areas, Inyo County, Calif. 


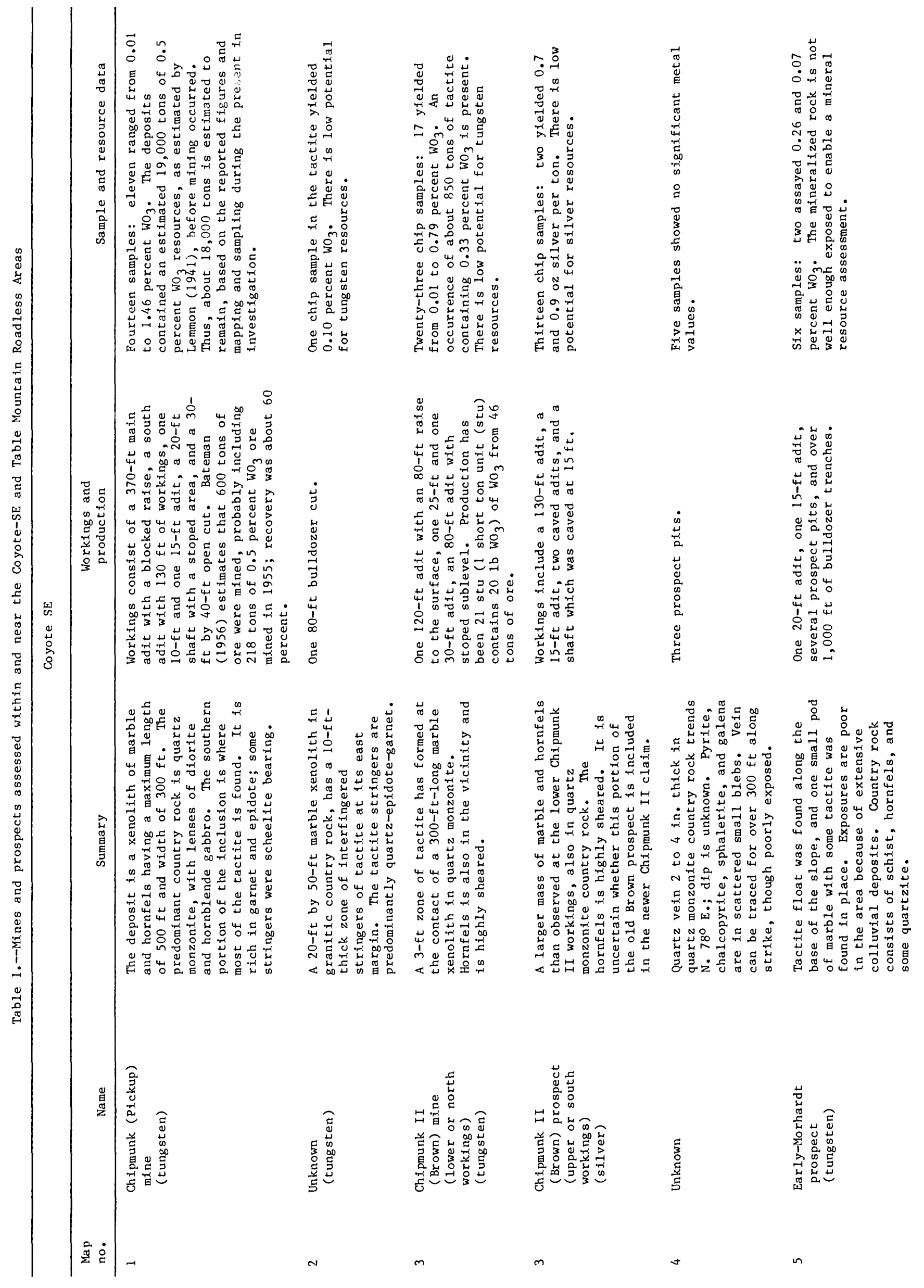



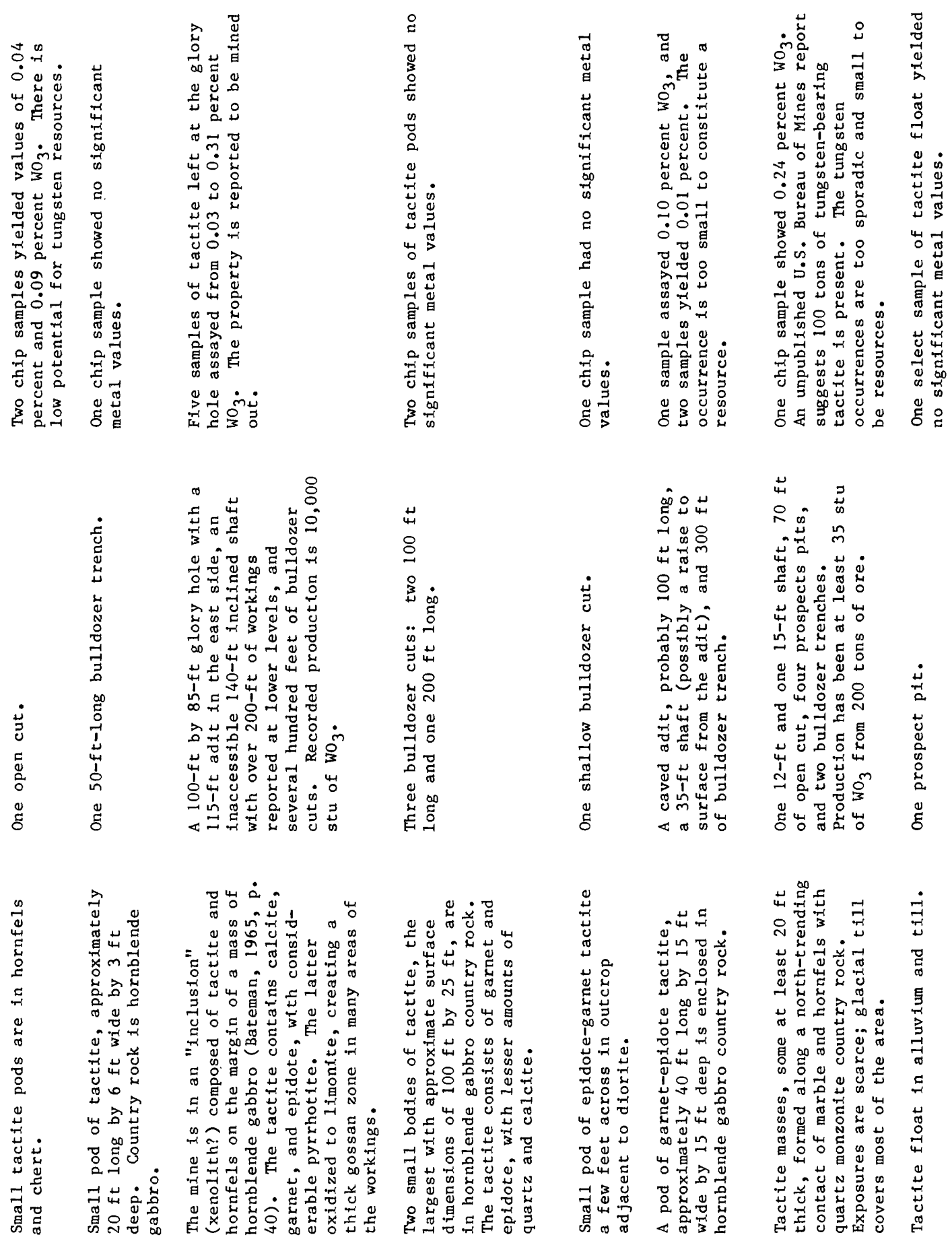

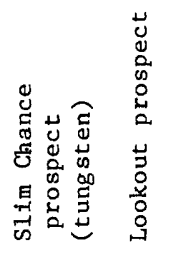
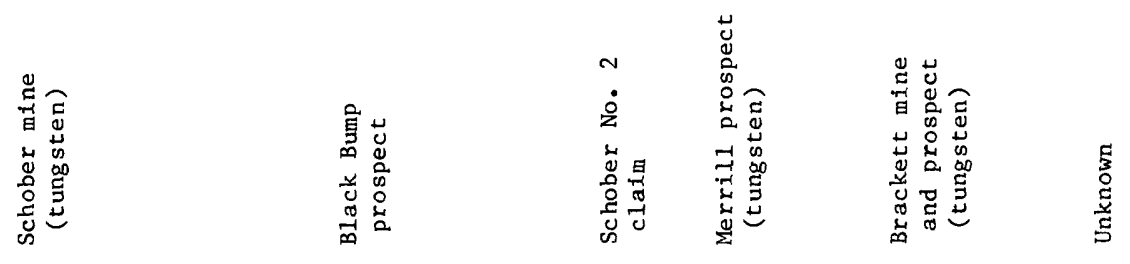
$\pm \stackrel{2}{2}$
$=$
$\stackrel{\infty}{-9}$
$\overrightarrow{\text { }}$
ก 


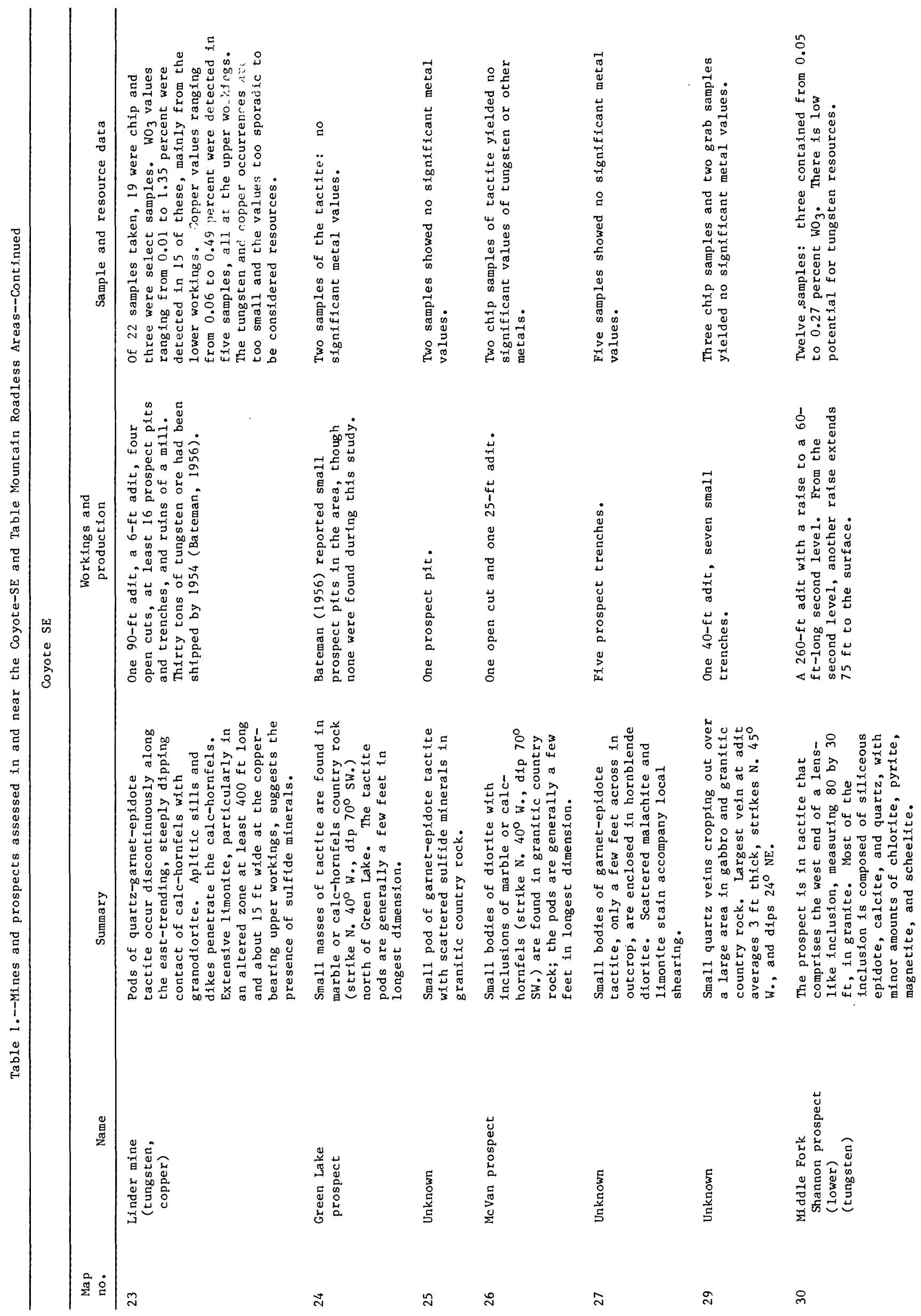



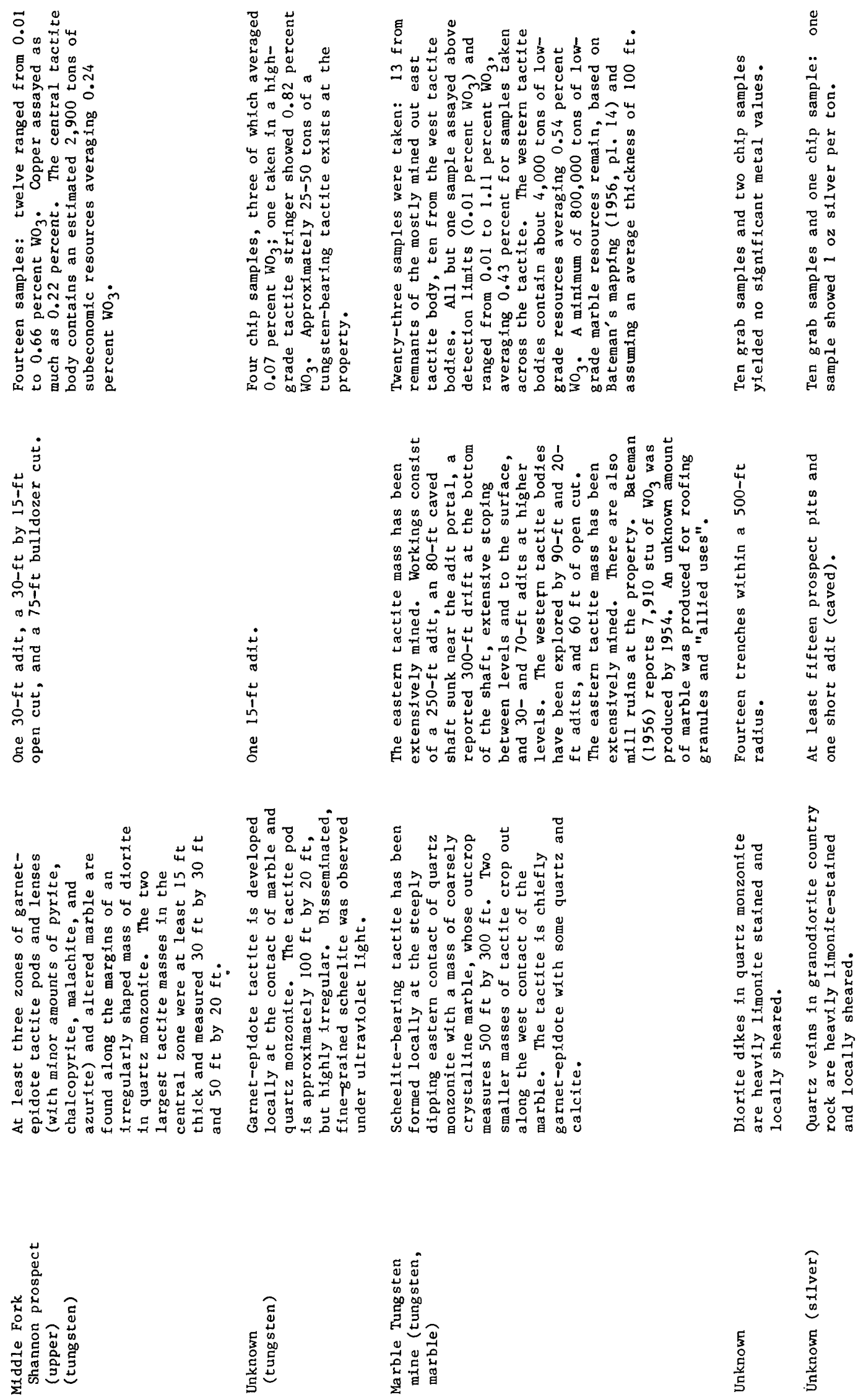

으

ले लै

m 


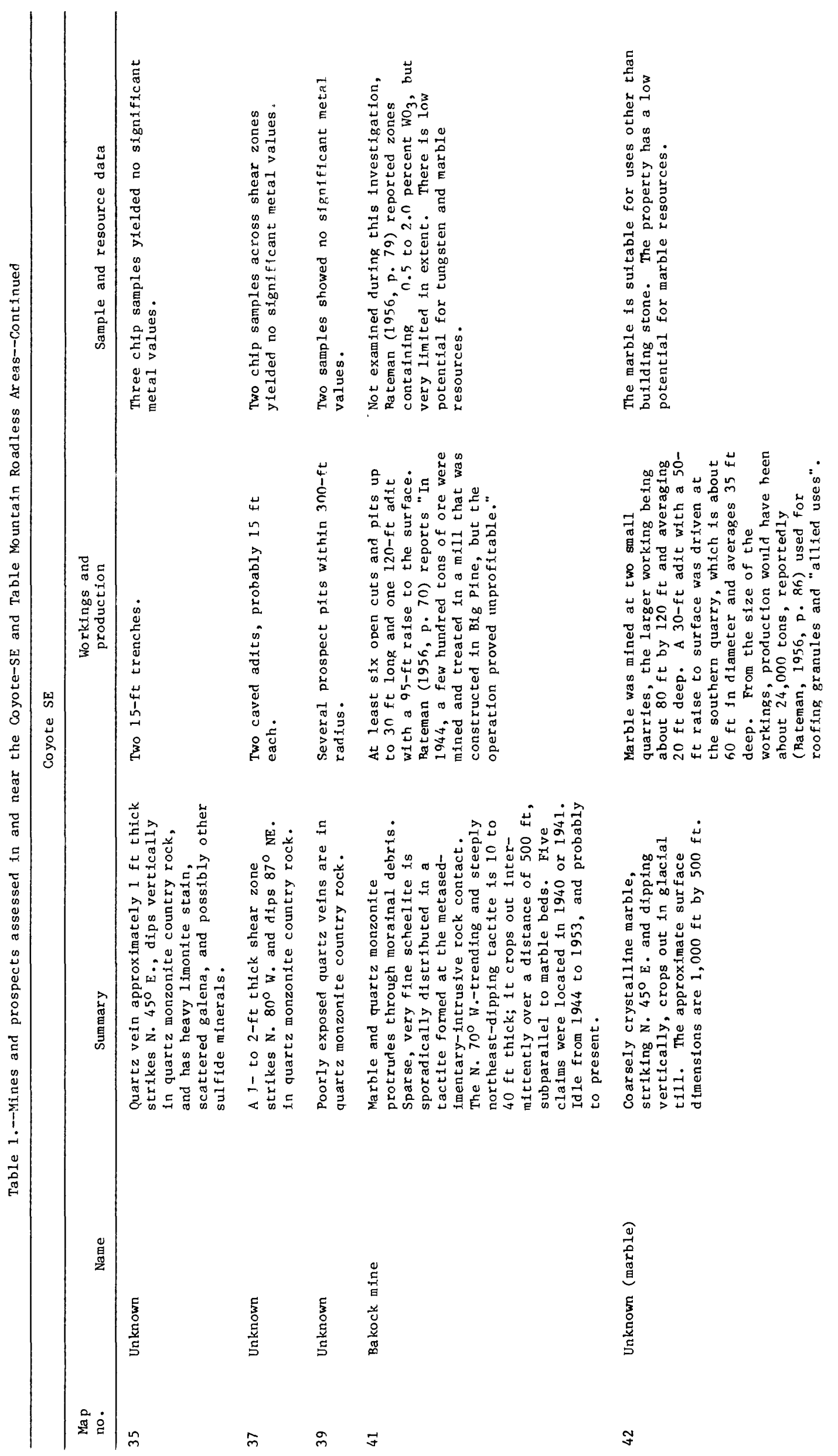




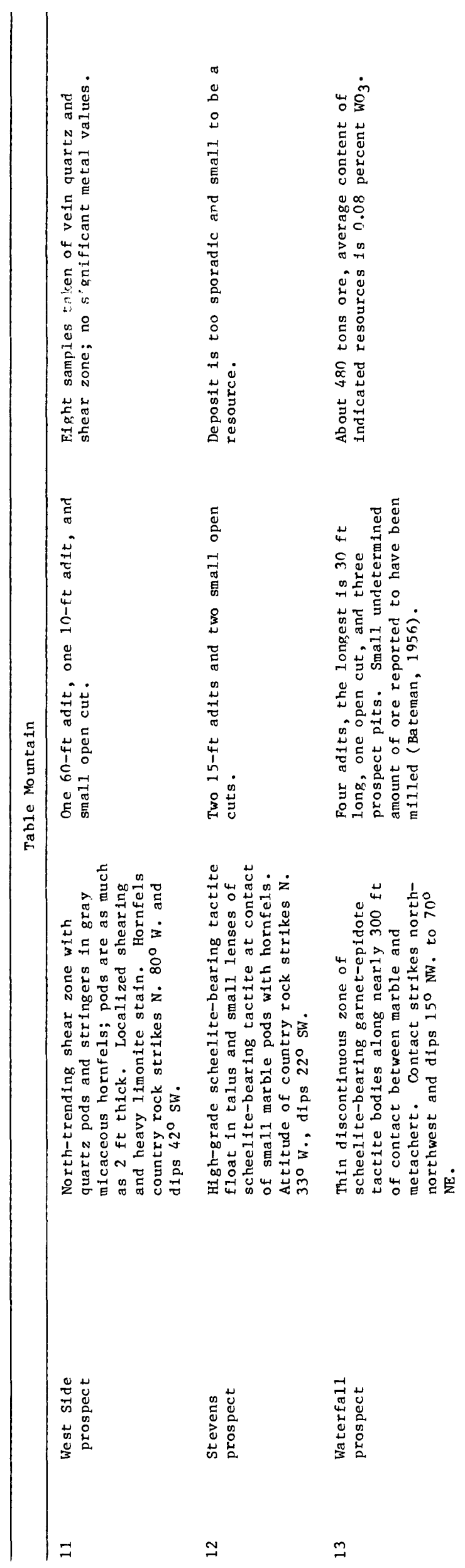


. 